\title{
Macro- and Microstructural Issues in Mazuna Lexicography ${ }^{1}$
}

\author{
P.A. Mavoungou, Department of Afrikaans and Dutch, \\ University of Stellenbosch, Stellenbosch, Republic of South Africa \\ (13126733@humarga.sun.ac.za)
}

\begin{abstract}
All the works in Mazuna lexicography have a common denominator: they are translation dictionaries biased towards French and were compiled by Catholic and Protestant missionaries or colonial administrators. These dictionaries have both strong and weak points. The macrostructure although it does not display features of sophistication, i.e. the use of niching and nesting procedures, tends to survey the full lexicon of the language which make these dictionaries real reservoirs of knowledge. The microstructure contains a lot of useful entries. However, no metalexicographic discussion is provided in the user's guide to make it accessible to the target reader. There are also some shortcomings especially in the areas of suprasegmental phonology (absence of tonal indications) and orthography.
\end{abstract}

Keywords: MACROSTRUCTURE, MICROSTRUCTURE, TARGET USERS, SPECIAL-FIELD TERMS, LEXICOGRAPHIC DATA, PROBLEM OF SOURCES, USERS' GUIDE, RESERVOIRS OF KNOWLEDGE, FAN.

Abstrait: Les problèmes macro- et microstructurels dans la lexicographie Mazuna. Tous les travaux en lexicographie Mazuna ont un dénominateur commun: ce sont des dictionnaires de traduction centrés sur le français et compilés par les missionnaires catholiques et protestants ou les administrateurs coloniaux. Ces dictionnaires ont à la fois des avantages et des inconvénients. Bien que ne présentant pas de caractéristiques de sophistication, par exemple l'usage de procédures de nichification et de nidification, la macrostructure tend à donner une vue d'ensemble du lexique de la langue, ce qui fait de ces dictionnaires de véritables réservoirs de connaissance. La microstructure contient de nombreuses entrées utiles. Mais aucune discussion métalexicographique n'est présentée dans le guide aux usagers pour les leurs rendre accessible. Il y a également des manquements, spécialement dans le domaine de la phonologie suprasegmentale (absence d'indications tonales) et de l'orthographe.

Mots-clés: MACROSTRUCTURE, MICROSTRUCTURE, PUBLIC CIBLE, TERMES DES LEXIQUES SPÉCIALISÉS, DONNÉES LEXICOGRAPHIQUES, PROBLĖMES DES SOURCES, GUIDE DES UTILISATEURS, RÉSERVOIRS DE CONNAISSANCE, FAN.

\section{Introduction}

Mazuna (which is the opening greeting formality "I say that") is according to Kwenzi-Mikala's classification (Kwenzi-Mikala 1998 and 1998a) the language group under which the six dialects of the Fan language are accommodated. $\mathrm{Fan}^{2}$ is the home language of 29 percent of the population (circa 427000 people) of Gabon. 
The speech forms of this group are mostly found in four of the nine provinces of Gabon, namely Estuaire, Moyen-Ogooué, Ogooué-Ivindo and WoleuNtem. Fan-Atsi is spoken in Ndjolé and Lambaréné, Fan-Make in Libreville and Kango, Fan-Mvaï is found in Minvoul, Fan-Ntumu in Oyem and Bitam, and Fan-Nzaman and Fan-Okak are spoken in the regions of Makokou-OvanBooué and Medouneu-Cocobeach-Mitzik respectively. Fan is a so-called crossborder language because it is also spoken in neighbouring countries, namely in Equatorial Guinea, Cameroon, São Tomé, Principé and the Republic of the Congo.

Up to the present, all the dictionaries available for the Fan language have a common denominator: they are translation dictionaries biased towards French and were compiled by Catholic and Protestant missionaries or colonial administrators. These dictionaries reveal a number of shortcomings that need to be remedied, e.g. most of these works neither mark tone, nor indicate the pronunciation of the treated items. To a greater or lesser degree, the earlier dictionaries lack a metalexicographic foundation. These shortcomings are excusable if one considers that their compilers were neither linguists, nor trained lexicographers (cf. Nyangone Assam and Mavoungou 2000).

In this article the attention will mainly focus on the macro- and microstructure of three contributions, namely Largeau (1901), Martrou (1924) and Galley (1964).

This paper implicitly works with the theoretical framework of Wiegand and Kučera (1981, 1982). According to them, when criticising dictionaries, one has to take the following components into consideration, namely: the history of the publisher, the dictionary basis, and the macro- and microstructure of the dictionary. This will be done and attention will also be given to the treatment of special-field terms before some concluding remarks are given (cf. Smit 1996: $30)$.

\section{The Encyclopédie pahouine of Largeau}

\subsection{The macrostructure of the work}

The Encyclopédie pahouine was published in 1901 by a colonial administrator. It is an alphabetically arranged dictionary of considerable size, consisting of \pm 4996 articles and covering 699 pages.

This dictionary is intended, in the first place, for speakers of Fan who want to translate French into Fan. In the second place, the dictionary is meant for speakers of French. It is a useful aid for foreigners visiting Gabon. It has been an indispensable tool in the economic sector and public administration for French, English and German businessmen operating in Gabon (especially in Woleu-Ntem and Moyen-Ogooué), because it is generally acknowledged that colonial administrations were no longer willing to rely on interpreters. The following is the comment of Courbon (1908) (quoted by Raponda-Walker 1998: 
83) as far as this point is concerned: "Ce sera ce dernier (l'interprète) qui jouira de l'influence réelle sur l'indigène, influence que son naturel joint aux circonstances tentatrices lui fera exploiter a son profit, au détriment des indigènes aussi bien que de son maître. Trop souvent, des malentendus, des revirements inexpliqués, des dissentiments, des "palabres» aux consèquences désastreuses ont été dus aux seules intrigues d'un interprètre tout d'abord préoccupé de ses propres intérêts."

Because Largeau's work is a monodirectional French-Fan publication, the lexicographer has not been confronted with the problematic aspects that African languages have in common nor with language-specific issues in Fan. The compiler adheres to the lemmatisation principles established in the European tradition, e.g. verbs are lemmatised under their infinitive form or under the first person singular of the present indicative, whereas nouns are entered under their complete form (cf. Hausmann and Wiegand 1989: 329).

In addition to the foregoing, it should be mentioned that different types of lexical units including multiword lexical units such as tout à coup, arc-en-ciel, tout à l'heure, etc. have been lemmatised in the encyclopedia. With regard to the scope of the work, lemmata have been taken from various fields, among others ethnology, religion, oral literature, metallurgy and astrology. As a large reference work it reflects the real language use and/or lexicon of the language.

With regard to the dictionary basis, a large lexicographic corpus was probably used. However, the lexicographer does indicate neither the primary sources (also called lexicographic corpus or dictionary basis which comprises all the sources that are not dictionaries themselves (cf. Smit 1996: 30-31 and 111)) nor the secondary (all the dictionaries consulted during the compilation phase (cf. Wiegand and Kučera 1981: 100ff)) and tertiary sources of his lemma collection. The compiler deserves some credit for providing the user with a relevant discussion on the pronunciation system, the orthography and the punctuation system used in the book as well as some morphological information such as the parts of speech, word-formation and the conjugation system of Fan that is abundantly illustrated by tables. But this presentation in the user's guidelines and the mini-grammar of the work reveals a number of shortcomings. Firstly, the writing system proposed by the compiler is very much along the lines of the orthographic traditions of French. It is a well attested fact that there is a difference between the sound systems of the African languages and those of the European languages. Consequently, the transcriptions proposed are likely to be only approximate. Moreover, the grammatical content is a bit outdated.

\subsection{The microstructure of the work}

Despite the alphabetical arrangement displayed by the lemmata, the encyclopedic character of the work lies in its focus on extra-linguistic features rather than on the meaning of lexical items. As already mentioned, this encyclopedic 
dictionary aims to present data as comprehensively as possible. The interesting fact that has to be mentioned is that the encyclopedia usually provides the user with a lot of contextual data. This point is illustrated in the article of the lemma AISELLE.

AISELLE (le dessous du bras), Mvagha, pl. me mvagha: je porterai ce paquet sous le bras (sous l'aiselle), me ke babe mbôm wele e mvagha'si (moi irai portant un paquet ce dans aiselle dessous).

Immediately after the lemma sign (in small capitals) appears, in parenthesis, the explanation "le dessous du bras" (the under arm (part of the body)), followed by the translation equivalent (in Italics) and the competence examples in both French (in roman) and Fan (in italics). The latter is followed by its literal translation, given in parenthesis. The systematic use of parenthesised explanations and word by word translations in the work correspond to the lexicographer's willingness to meet the requirements of pedagogical lexicography. Another feature of the dictionary is the use of typographical markers. For example, in the article of the lemma CHANSON, encyclopedic data is presented in both source language (to the left) and target language (to the right) in two columns set apart typographically, and therefore clearly perceived by the user.

CHANSON, $z a$, pl. bia. Voici une chanson que chantaient quelquefois nos anciens compagnons pahouins pendant nos courses à travers le Congo; elle est en dialecte bedži.

ZA NGOÏA

Ébon'i ne e Mellan̈, ...
CHANSON D'EXPIATION

Le coucher est aux Nénuphars, ...

In (2) the user is provided with the singular and plural forms of the translation equivalent following the item giving the lemma sign. Then the lexicographer, after a short introduction of what is about to follow, gives in extenso a popular Fan song. A number of articles, MORT, DESCENDANCE, CRÉATION, CON$\mathrm{TE}$, etc. have the same bilingual presentation. The Fan constituent of all these articles can be expanded and used for the compilation of a monolingual dictionary of Fan, for example.

In addition to the foregoing, the lexicographer has sometimes thought that more data regarding the cultural context of the lemmata dealt with were necessary for a better understanding of the treated lexical item. To fulfil these anticipated expectations on the part of the users, Largeau has devised special articles divided into two sections or search areas (cf. Hausmann and Wiegand 1989: 339). The presentation of these articles is very much the same as that used in synopsis articles. In the first search area, the compiler basically deals with linguistic aspects whereas in the second (introduced by the word Encyclopédie), the focus is on the cultural aspect of the lemma treated. This intrastructural marker (cf. Gouws 1996: 24-25) (Encyclopédie) helps the user with a quick and successful retrieval of the needed information because it clearly indicates the relevant article position. As such it forms part of the rapid inner access struc- 
ture (Hausmann and Wiegand 1989: 338). Instead of going through the whole article the user who is merely interested in cultural data can immediately proceed along the inner search path (the outer search path ends at the lemma sign) to the article position Encyclopédie and continue from there through the remainder of the article. This point is illustrated by the treatment of the lemma FEMME.

(3) FEMME: $1^{\circ}$ en général, nga, pl. be ya; $-2^{\circ}$ femme accompli, qui donne des enfants, une dame, Mö̈ga, pl. bonga;

Encyclopédie: la femme; sa situation dans la famille; ses droits et devoirs....

From the data presented in these articles (cf. (2) and (3)) with a strong ethnographical interest, the user can retrieve a lot of information regarding the lifestyle, value system, the beliefs, in brief, the world vision of the Fan people. The strong inclination towards ethnographical data qualifies the encyclopedia to be classified in the subtype of the so-called ethnographical dictionary. According to Zgusta (1987: 14) an ethnographical dictionary is "a dictionary that tries to describe a culture in the entries of the single relevant words". Although credit should be given to these cultural explanations, they reveal a number of shortcomings. Firstly, objections can be made with regard to the absence of metatexts in the user's guidelines explaining the structure of these articles as well as the types of data categories presented in them. Secondly, the cultural analysis of certain treatment units reflects the observation of the colonizing over the colonized. For example, as far as the question of anthropophagy among the Bafan is concerned, there is no doubt that Largeau was aware of the fact that anthropophagy was a very marginal phenomenon in this community. However, quite a significant amount of co-text examples and cultural comments do highlight this practice. This is likely to create a false impression in the mind of the users that the Fan community is anthropophagous. But it has been proven by some scholars of ethnology (Roulet (1866), Deschamps (1962), Du Chaillu (1863) and Metegue N'nah (1984) among others) that anthropophagy was restricted to a very small group of people. Moreover, only one piece of the body of the avowed enemy killed during the war was eaten out of revenge in order to completely destroy any existence of him. Largeau (1901: 337 and 367) is correct when stating that women and children were excluded from these anthropophagous meals. The aspect under discussion and others which are derived from an outmoded and dated Eurocentric vision should be removed from the work. The user profile has to be taken into account in order to achieve this goal. Largeau deserves credit for painting the Fan society through its origin, rituals, mythology, wars, hospitality, etc. However, he could not avoid the trap of cliché and personal judgments. As a result, some of his examples and comments often illustrate his own personal attitude towards the people described. It is well accepted that lexicographic data should illustrate an unbiased, impartial use of the language. 


\subsubsection{Concluding remarks}

Althrough a large lexicographic corpus was used in Largeau's Encyclopaedia, the introductory section fails to indicate the primary as well as the secondary sources of the work. Due to the monodirectional nature of the work (FrenchFan), the compiler adheres to the lemmatisation principles established in the European tradition. In the central list, one finds a lot of interesting articles in which medio-structural (cross-referencing), data distribution procedures and typographical exposition (to list but a few) come into play. The latter, especially, the use of different font types (italics, small capitals, etc.), the bilingual presentation of articles divided into search areas set apart typographically, special articles focusing on cultural data introduced by the intra-structural marker Encyclopédie as well as the systematic use of literal translations addressed at the translation equivalents and competence examples have drastically improved the quality of the work. Ordering devices are given as a visual aid to the users whereas contextual data in the form of word by word translations help them to disambiguate the different senses of the treated lexical items. Competence examples and comments with a strong cultural load make the Encyclopédie a valuable reservoir of knowledge. Unfortunately they sometimes reflect the lexicographer's personal judgement.

\section{Martrou's Lexique fãn-français}

\subsection{The macrostructure of the lexicon}

In his Fan-French lexicon (1924) Martrou presents 3431 articles with guiding elements arranged in a strict alphabetical order. The compiler of the lexicon deserves credit for explaining his writing system. The orthography employed in the lexicon is based on the principles expounded by Ch. Sarcleux in his book Essai phonétique. The fact that the work contains information on stress in the lemmata (according to Martrou tonic accent in Fan is characterised by a global rise and the lengthening of the syllable and is indicated by the stress mark (')) is an indication of the lexicographer's awareness of the necessity of giving an account of the pronunciation of the language.

Martrou does not mention which other dictionaries he consulted. Since no explanation is given as far as the primary sources of the lexicon is concerned, the work seems to have no lexicographic corpus of its own.

The lexicon contains lemmata in Fan and translation equivalents in French. To enhance the identification of entries, the compiler used a lot of typographical structural markers such as roman, italic, bold and small characters. The fact that lemmata have been set in large and small capital letters and the use of running heads have improved the access structure of the lexicon. 
Different types of lexical items have been given lemma status in the lexicon. This includes nouns, verbs, adjectives, pronouns, etc. entered in the lexicon according to the word tradition.

With such a word-based approach, the lexicographer does not make provision for the inclusion of word-formation items (affixes (prefixes, suffixes and infixes) and stems).

Unfortunately, the users' guidelines of the lexicon do not answer the question likely to arise: on which ground has the selection of items taken place?

\subsection{The microstructure of the lexicon}

The microstructure includes some data, e.g. the paraphrase of meaning, translation equivalent (s), and examples. Compare the article of the lemma Nkor:

(4) Nkor. Courbe. Adj. Crochu, replié. Ambigu, tortueux. Nkor osu. Rivière à méandres. Nkor ntẽm. Branche recourbée. Nkor adzu. Affaire ambiguë.

The translation equivalent paradigm appears immediately after the item giving the form of the lemma sign. Then the user is provided with the relevant examples in the source language (in italics) as well as their translation equivalents in the target language (in roman). The interesting fact to be mentioned here is that the item giving the part of speech (Adj.) is not addressed at the lemma, but has a non-lemmatic address. In other words, it is addressed at the translation equivalent "crochu". The same line of argumentation holds true for the presentation of contextual data. The target language examples are addressed at the source language competence examples. Thus the latter become treatment units or new topics within the article. Here it seems that, as for Fan, French has been given the status of language of treatment shifting the focus from the source to the target language (cf. Gouws 1996: 158). When first looking at the microstructure of the work, it seems that the lexicographer has decided not to give grammatical items for the lemma type NOUN. Only when dealing with lemma signs which are interpreted as polyfunctional, i.e. when lemmata can function as a noun or a verb, the grammatical item is given. This corresponds to a practice also followed in other dictionaries. For example, Smit (1996: 192) focusing on the treatment of the lemma gesalf'de has pointed out that the Verklarende Handwoordeboek van die Afrikaanse Taal (HAT) "does not give the same data types for all lemma types NOUN." This system has of course to be explained in the user's guidelines of the dictionary. However, the treatment of lemma types VERB and ADJECTIVE (to list but a few) reveals inconsistencies. For example, in the articles of the lemma signs sèroe and seroe, it is not indicated that these lemmata are verbs, whereas in the treatment of the lemmata sa and Nkũnoe entries indicating part of speech are presented. In addition, why does the lexicographer give data regarding the part of speech in an article like Ntul (adj. meaning "old") but fails to do the same for the majority of nouns, some verbs, etc.? Since there is no text explaining the system, it can be assumed that no 
fixed criteria were worked out for the different lemma types. The lexicographer too often fails to provide the user with a useful entry: the item giving the part of speech of the lemma sign. This point is illustrated in the article of the lemma Abum.

Abum. Abdomen, ventre. Ekõ abum, avoir mal au ventre. Abum d'alurce a, il a la diarrhée - Grossesse ... - intérieur d'un object creux ... - devant ... Grosseur ... - Grosseur moyenne ...

Immediately after the item giving the form of the lemma sign, the users are provided with a mere list of translation equivalents. This is unacceptable because the way in which an item is lemmatised should give an account of its morphological status. As far as this point is concerned (cf. Hausmann and Wiegand 1989: 353), dictionary articles usually display both macro- and microstructural data. The first data types are referred to as the comment on form (e.g. spelling and part of speech) whereas the second data categories are known as the comment on semantics (e.g. monosemy or polysemy, meaning paraphrase). When dealing with the lemma Abum the user is at a loss because he/she does not know whether it is a noun, a verb or an adjective. As a matter of fact, Abum is a noun. Each cotext example given in this article activates one sense of the lemma Abum. The latter also points out an interesting feature of the lexicon: the use of a textual condensation device which decreases the data types in order to save space (cf. Gouws and Prinsloo 1997: 51-55). Employing a textual condensation approach, the lexicographer has used the hyphen to substitute the lemma in the illustrative examples. The question to be addressed here is whether this use of a textual condensation procedure corresponds to the needs and reference skills of the potential users of the dictionary. Since the lexicon does not explicitly identify its target reader, the latter is assumed to be high school pupils, students, scholars and learners. This has a lot of implications as far as the data types to be included in a lexicographic work as well as their presentation are concerned. Lexicographers usually make use of textual condensation devices where the target users of a dictionary have a long tradition of dictionary consultation (cf. Gouws 1999: 33). As a matter of fact, the Gabonese community in general and the Fan people in particular are not well familiar with dictionary using skills. According to the treatment given in the lexicon, the lemma Abum can be regarded as a polyfunctional lemma in the sense that it mainly appears with verbs and later with nouns, but can also be used as an adverb.

Therefore, instead of using a system of textual condensation the lexicographer should have employed structural markers (I, II, III, ...) to indicate the different cotexts in which the lemma sign Abum can possibly occur. These structural indicators are not to be seen as markers of polysemy but they are part of the inner rapid access structure (cf. Hausmann and Wiegand 1989: 356). They should not be presented in a haphazard way but according to a predetermined set of criteria accounted for in the relevant front matter text. These criteria 
should include the use of usage frequency as a presentation asset as well as other principles of arrangement.

\subsubsection{Concluding remarks}

Like Largeau's encyclopedia, Martrou's lexicon fails to give an account of its primary and secondary sources. The fact that has to be mentioned is that the use of different font types (roman, bold, italic, etc.) as well as the running heads have improved the access structure of the work.

With regard to language-specific issues, lexical items have been entered in the lexicon according to the word tradition. Unfortunately the criteria of incorporation of these lexical items is not accounted for in the front matter of the lexicon. The microstructure of the work provides the users with various data categories: paraphrase of meaning, translation equivalents, competence examples, etc. However the lexicographer too often fails to provide the users with a useful entry: the item giving the part of speech of the lemma sign. The lexicon does not clearly identify its target users as well as their reference skills. Consequently no fixed criteria were worked out for the different lemma types and one finds in some articles a nonmotivated use of textual condensation.

\section{Galley's Dictionnaire fang-français et français-fang}

\subsection{The macrostructure of the dictionary}

The macrostructure of Galley's Fan-French and French-Fan dictionary (1964) contains \pm 13925 articles listed in strict alphabetical order. It is a record of the language as it is used by the Fan community of Talagouga (around Ndjolé). As far as the scope of the dictionary is concerned, the compiler has included words used in everyday speech, geographic names, plant and animal names, proper names and idiomatic expressions as part of his macrostructural elements. It is really a representative collection of Fan lexical items in use in Talagouga. There is no doubt that the compiler wanted his dictionary to be a real container of knowledge (McArthur 1985). However, the compiler or in this case the publisher did not mention the criteria according to which lexical items have been lemmatised in the dictionary. This kind of information is usually found in the user's guide in the front matter of the dictionary. The preface of the dictionary merely states why the Association Française des Amis d'Albert Schweitzer has decided to publish Galley's work. This introductory section also gives a brief outline of Galley's missionary, lexicographic and pedagogical activities. But nothing is mentioned as far as the selection of lemmata is concerned. There are several questions likely to arise:

- What are the primary and secondary sources of the dictionary?

- Who are the target users? 
- What are the needs and reference skills of the target user of the dictionary?

The above-mentioned questions are not fully addressed in the front matter of the dictionary. Therefore, one has to guess the sources of the dictionary. As far as the primary sources are concerned, the guide to the dictionary clearly states that the work is based on the translation of the Bible in Fan that Galley did over a period of 40 years for the Fan community of Talagouga. Special mention is also made of the help of Galley's interpreter: Obam Mendôme. The secondary sources of the dictionary are not explicitly discussed in the instruction book. The preface does mention the existence of an earlier lexicographic work with restricted macrostructural elements. Most probably it is the lexicon Fan-French compiled by Martrou.

Another aspect of the dictionary is that the compiler has not dealt with Fan alone but has stated the relationship between Fan and other Bantu languages as it occurs in the article of the lemma ABAÑ .

(6) $\mathbf{A B A N ̃}(b)$ n. 4, pl. mebañ. Arbre à bois dur. En Galwa: mandji. Nom commercial: iroko (Chlorophora excelsa).

With the entry "En Galwa: mandji" the lexicographer refers the users to the item denoting the lemma ABAÑ in Ghalwa, a dialect of the Omyene language. This is not surprising if one takes into account that the Fan community of Talagouga and the speakers of Ghalwa live in harmony in the Moyen-Ogooué province and this language contact also results in language borrowing. However, objections can be made with regard to the lack of explanations in the user's guide as far as the system applied by the lexicographer is concerned.

It seems that the lexicographer took into consideration all existing dictionaries and reference works that were of interest for the building up of its own dictionary corpus. These include all the grammar books, religious studies, and syllabi available in Fan at the time of the compilation phase.

However, a close look at the central word list, specifically in the article of Mvep, leads to one of the secondary sources of Galley's dictionary:

(7) Mvep (h) n. 3, pl. bemvep Rongeur, appelé en anglais canerat, rat de canne à sucre ..., Largeau dit le même mot. ...

The treatment of the above-mentioned lemma witnesses the fact that Galley has used the Encyclopédie pahouine by Largeau (1901) as a secondary source for the compilation of his dictionary. As a matter of fact, Largeau's work is based on the dialects Atsi and Make. Moreover, it is very possible that Galley did not only consult Largeau's encyclopaedia, but also all earlier lexicographic works in Fan. As far as the French-Fan section is concerned, monolingual or bilingual dictionaries of French published during the period concerned are most probably the secondary sources of the work.

Even if the introductory section claims that the dictionary is not aimed at a sophisticated public because Galley has deliberately left out the phonetic tran- 
scription of his treatment units, it seems that the work is intended to meet the needs and reference skills of students, scholars and people who wish to learn the language. André-Charles Henry (in the preface to Galley's dictionary) is correct when stating that Galley's work is not a book for well-informed people. It is not reserved for initiates. Indeed, the medium used in the dictionary is everything except hermetic. In fact Galley does not want to sound intellectual. His definitions are simple and concise. But the inclusion of data categories such as class numbers, word-formation, structural markers, etymology, definitions, synonyms and homonyms presupposes a sound linguistic knowledge on the part of the target user, even if one does include a mini-grammar as a back matter text. The target users of the dictionary is likely to be scholars and students. Even so the user still needs some guidelines explaining to him/her all the component parts of the dictionary.

In contrast to earlier dictionaries such as the works by Marling (1872), Lejeune (1892) or Martrou (1924), Galley's dictionary is intended to meet the needs of both speakers of Fan and French because of its bidirectional feature. Another feature of the dictionary concerns the access structure: the use of typographical markers such as the presentation of the lemmata in bold small capitals as well as the running heads of the columns which form the outer rapid access structure (Hausmann and Wiegand 1989: 329) make it easier for users to find the word which they are looking for.

\subsubsection{The microstructure of the dictionary}

The microstructure of the dictionary includes a lot of data, e.g. the part of speech, class number, translation equivalents, meaning explanation as well as cross-references. The lemma is immediately and systematically followed by a tonal indication. This entry is of great importance to the user. Very often, lexicographers compiling dictionaries for African languages have been guilty of ignoring this basic component of the phonological analysis of the language. Galley distinguishes three tone heights in his dictionary, namely: the high tone $(\mathrm{h})$, the low tone $(\mathrm{b})$ and the medium tone $(\mathrm{m})$. Furthermore, one of the front matter texts gives an account of tonal features. The tonal indication is usually followed by a paraphrase of meaning in the target language (French). As far as this point is concerned, a paraphrase of meaning in the source language (Fan) will have empowered the speakers of Fan to a larger degree. Therefore, the dictionary is more likely to meet the needs of the speakers of French than those of Fan. Compare the article of the lemma Mvia:

(8) Mvia (h) n. 2, pl. mimvia (vb via h). Femme acquise avec la dot de notre fille. En d'autre termes, femme achetée par le beau-père avec la dot reçu de son gendre. Et sa fille dont la dot a été prise pour cela, c'est sa mbala (voir ce mot).

Following the tonal indication the user finds the paraphrase of meaning. Moreover, when dealing with the meaning, the compiler also makes provision for 
information regarding distinctions in meaning (which refers to the polysemic values of one lexical item) (cf. Training Course of the Bureau of the WAT). Consider the following lemma:

ABANA (h) n. 4, pl. mebana (vb ban h). Abana zal, fétiche enfoui dans la terre et qui garde le village. Abana mon, fétiche pour que le bébé ne tette plus sa mère et qu'elle puisse avoir un autre enfant. Abana nsôm, fétiche qu'un ennemi fait au chasseur pour l'empêcher de tuer.

The syntagms Abana mon and Abana nsôm reflect polysemic expansions of the meaning of the lemma ABANA ("fétiche enfoui dans la terre et qui garde le village") contained in the syntagm Abana zal. Another interesting feature of the dictionary is the treatment of polysemic terms (lexical items with more than one sense). Compare the treatment of the lemma ABEÑY:

ABEÑY (b) n. 4, pl. mebeñle. 1. Pincettes de forgeron pour tenir le fer rouge. -2. Mirliton du chanteur de la danse $a k \hat{m}, \ldots-3$. Barre ou plaque de fer ou d'un autre métal. - 4. Museau allongé du crocodile ou de la civette moakh. 5. Balle de fusil ou cartouche. - 6. Abeñy ndame, chevalet à deux $X$ en pente où l'on met en position penchée les lianes à caoutchouc coupées pour en recueillir le latex. - 7. Abeñy ntsap, barre de savon. - 8. Abeñy ébom, système de fer qui ferme la cangue du prisonnier. - 9. Abeñy e nżel, grande barbe.

In (10), the lexicographer provides the users with data categories accomodated in sections of the article, i.e. the "comment on form" (CF) and the "comment on semantics" (CS) (Hausmann and Wiegand 1989: 353). The entries such as the lemma sign (ABEÑY), tonal pattern (b), class number (n. 4) and plural indication (mebeñle) which appear in the left core structure of the dictionary article are part of the $\mathrm{CF}$, the rest of the entries on the right core structure of the article belong to the CS (cf. Hausmann and Wiegand 1989: 353-354). Furthermore, the user can regard the lemma ABEÑY as representing a polysemous lexical item. Each sense is introduced by a structural indicator or marker 1, 2, ... 9 which form part of the inner rapid access structure of the dictionary (cf. Hausmann and Wiegand 1989: 354-356).

In the article of a polysemic lemma such as in (10), the different distinctions in meaning should not be presented on a random basis but according to fixed criteria which should also be explained in one of the front matter texts. For the lemma ABEÑY, one has to guess the principles of arrangement. It seems that the compiler has made the arrangement according to primary and secondary distinctions in meaning. Or more probably, for this example, the arrangement has been made according to the principle of conjunctive and disjunctive distinctions in meaning. Sense 1 of the lemma sign seems to be the literal polysemic value of the lexical item, therefore it is placed first in the article. Senses 2, 3, 4, 5, 6, 7, 8 and 9 seem to be metaphorical extensions of the first sense. Moreover, senses 2, 3, 5, 6 and 8 have more or less related meanings. Because they all have something to do with the lexical item iron or with metallurgy. Thus they should have been arranged by the lexicographer in the above- 
mentioned order. Senses 7 and 9, in which the figurative meaning does not refer directly to the first subcomment on semantics, could have been introduced later in the listing. Of course another principle of arrangement could also have been used by the compiler, namely: the principle of empirical arrangement in which distinctions in meaning are determined on the basis of frequency counts (cf. Training Course of the Bureau of the WAT 17-20).

This article of ABEÑY also highlights some aspects of the presentation of compounds which reveals some inconsistencies in the dictionary. Abeñy ndame, Abeñy ntsap, Abeñy ébom and Abeñy e nżel are compounds with the structure: noun plus (connective) noun and they are all written without hyphen. However, the following lemmata: MÔR-A-MVAM, MVAKH-FÎN and AKAMNYAR are all presented with hyphens.

The treatment of homonyms also reveals some shortcomings. Consider the following example in this respect:

(11) $\quad$ ABI (b) (lg) n. 4, pl. mebi. Cuisse ...

ABI (h) (bf) n. 4. ss pl. Mal, péché, ...

ABI (h) (bf) adj. Sing. ....Mauvais, ...

ABI (h) (lg) n. 4, pl. mebi. 1. Sein, ...

The last three treatment units of the above-mentioned paradigm which, according to the compiler, have the same tonal pattern $(h)$ have been given lemma status as homonyms. The question arises on what grounds the target user of the dictionary is going to distinguish between those three members of the homonym paradigm? They should have received superscript numbers, or start with a structural indicator, reflecting frequency of use as it is usually done in such cases. For example, ${ }^{1} \mathbf{A B I} ;{ }^{2} \mathbf{A B I} ;{ }^{3} \mathbf{A B I}$ or $\mathbf{1}$. ABI; 2 . ABI; 3. ABI. Numerous examples could be listed to illustrate this systematic shortcoming in the dictionary.

Another feature of the dictionary is the treatment of special-field terms and cultural concepts. Compare the treatment of the article of the lemma ABYÔM:

(12) ABYÔM (h) n. 4, pl. mebyôm. Chasse à environ 50 hommes, avec grands filets et chiens. Il peut y avoir 300 mètres de filets. 20 hommes restent près des filets, et les 30 autres s'éloignent pour rabattre le gibier qui consiste surtout en antilopes. Syn.: ézakh (b). Proverbe: Wa tô abyôm ñkîa, ndôkh mveñ za ña ke noñ $n d u m$, tu as refusé d'aller à la chasse de ton beau-père, mais il va pleuvoir, et tout le monde restera assis au village, et toi comme les autres.

The compiler starts with a meaning explanation of the lemma ABYÔM. Then a full explanation is given of how the hunting takes place and the number of the participants. Those explanations which concentrate mainly on extra-linguistic features are indeed not part of the paraphrase of meaning or definiens. However, they highlight some cultural aspects of the life of the Bafan. The user can retrieve a lot of useful information from these entries. One of the ways for lexicographers to give an account of cultural explanations without giving too much 
encyclopedic information in the paraphrase of meaning is the use of synopsis articles.

It is also important to mention how the compiler deals with plant names. Consider the following example:

TÔM (b) n. 3, pl. metôm. Grand arbre parasol. Nom commercial d'après Meniaud: Tsoumbou. (Nom scientifique: Parkia Klainei Pierre). Couleur du bois: gris jaune. Arbre magnifique à voir. Tôlba tôm (vb tole h), se faire verser goutte à goutte une infusion de bois de tôm dans l'œil, comme épreuve pour savoir si l'adultère a été commis (ordalie).

MVON (b) n. 3, pl. bemvon. Gros singe à long poils noirs (fourrure), colobe (Colobus Satanas)....

(13) contains the following entries: tonal indication (bm), part of speech (n.), plural indication (metôm), scientific name, description and uses of the tree and label. In (8), the compiler basically provides the user with a sophisticated entry: the scientific name of the animal. Except for a few examples (not necessary to be mentioned) where the compiler fails to provide the user with entries such as the scientific name (of the plant or animal concerned), uses of the plant as well as the sources consulted, the treatment of special-field words has been done quite satisfactorily as far as the cultural context is concerned. The user is provided with lexicographic data concerning the fauna and the flora of the natural habitat of the Fan people. Besides leaves, roots and barks, fruits, seeds and animal ingredients are listed with their uses in the folk medicines. All these data regarding the cultural context of the lemmata treated are very important for the user who is likely to find plants and animal ingredients displayed for sale on markets.

In the French-Fan section of the dictionary, macrostructural elements most probably belong to the everyday vocabulary of French.

The microstructure usually provides the target user with the following data: translation equivalent in Fan, sometimes preceded by a synonym or synonyms of the lemma in French, and examples (each example in French is immediately followed by its Fan counterpart). Articles vary in length. An extreme illustration is the treatment of the article of the lemma ARBRE (almost three columns in length):

(15) ARBRE bois, éli (h). Boîte en bois, évora éli (bh)....

The length of the article is the result of the compiler's listing of some 200 trees of the Gabonese forest as well as their uses and descriptions. Moreover, the commercial name of the tree appears with its indigenous name. The lexicographer has tried to deal with special-field lexical items on an equal basis as far as the two sections of the dictionary are concerned. Unfortunately, the abovementioned article has quite an unusual structure and thus deserves some explanation in one of the outer texts of the dictionary. 


\subsubsection{Concluding remarks}

To a greater or lesser degree, the front matter of the dictionary gives enough information regarding the primary sources of the work. However, it fails to give an account of its secondary sources. There is no doubt that the compiler has used a large lexicographic corpus of the language which makes the dictionary a valuable source of reference and a real container of knowledge.

Macrostructural elements have been selected from various fields (oral tradition, religion, forestry, traditional pharmacopoeia among others). Unfortunately, the lexicographer gives no assessment for incorporation. In addition, the macrostructure does not show features of sophistication, i.e. the use of niching and nesting procedures. The microstructure contains a lot of useful entries. But, no metalexicographic discussion is provided in the user's guide to make it accessible to the target reader. Special-field lexical items are treated in a satisfactory way in the sense that the metalanguage used is accessible for nonspecialist users. Description of medicinal and medico-magic plants are of importance for the user to understand the richness of Fan culture.

\section{Conclusion}

The contributions under discussion represent dictionaries supplying the same kind of lexicographic data. The macrostructure tends to survey the full vocabulary of the language. Special-field lexical items have received some attention to ensure a good retrieval of cultural information on the side of the users. The microstructure of the dictionaries under discussion includes a lot of data, e.g. word-class indications, paraphrase of meaning, translation equivalents, examples, etc. Despite all the good points, there are still some shortcomings especially in the areas of suprasegmental phonology (absence of tonal indications), metalexicography (consistent lack of guidance addressed at the users) and orthography. These dictionaries can hardly be used to solve writing problems on the part of the users because of the lack of uniformity as far as orthographical conventions are concerned. For example Alexandre (1961) (quoted by Kidda Awak 1980: 11) points out that the Fan language has acquired "trois transcriptions [catholiques] et deux [protestants] pour environ un million de locuteurs, sans parler des différences morphologiques dues à des calques catholiques sur l'allemand, le français et l'espagnol, et protestants, sur l'américain". To be used in the most efficient way, these dictionaries need to be updated according to the new set of orthographic symbols for the Gabonese languages.

\section{Notes}

1. I wish to express my gratitude to Prof. R.H. Gouws, my promoter, for encouraging me to write scientific papers and for making invaluable suggestions on the improvement of this article. 
2. In this article I use the official Gabonese spelling and not the traditional semiphonetic spelling employed by Guthrie, Jacquot, Kwenzi-Mikala and others. The underlined $\underline{e}$ and $\underline{n}$ represent $[\varepsilon]$ and $[\eta]$ respectively. The phonetic sound [ə] is represented by the symbol $ə$ in

Gabonese orthography. However, for phonological and practical reasons I have chosen to represent [ə] by a, as in Make.

\section{Bibliography}

Bureau of the WAT. Training Course of the Woordeboek van die Afrikaanse Taal (WAT). Stellenbosch: Bureau of the WAT.

Deschamps, H. 1962. Traditions orales et archives au Gabon. Paris: Berger-Levrault.

Du Chaillu, P.B. 1863. Voyages et aventures dans l'Afrique équatoriale. Paris: Michel Levy.

Galley, S. 1964. Dictionnaire fang-français et français-fang, suivi d'une grammaire fang. Neuchâtel: Henri Messeiller.

Gouws, R.H. 1996. Bilingual Dictionaries and Communicative Equivalence for a Multilingual Society. Lexikos 6: 15-31.

Gouws, R.H. 1999. A Theoretically Motivated Model for the Lexicographic Processes of the National Lexicographic Units. Research report submitted to the Pan South African Language Board.

Gouws, R.H. and D.J. Prinsloo. 1998. Cross-Referencing as a Lexicographic Device. Lexikos 8: 17-36.

Grimes, B.F. $1996^{13}$. Ethnologue. Dallas: Summer Institute of Linguistics, Inc.

Guthrie, M. 1953. The Bantu Languages of Western Equatorial Africa. Oxford: Oxford University Press.

Hausmann, F.J. and H.E. Wiegand. 1989. Component Parts and Structures of General Monolingual Dictionaries: A Survey. Hausmann, F.J. et al. (Eds.). 1989-1991. Wörterbücher. Ein internationales Handbuch zur Lexikographie / Dictionaries. An International Encyclopedia of Lexicography / Dictionnaires. Encyclopédie internationale de lexicographie: 328-360. Berlin: Walter de Gruyter.

Jacquot, A. 1978. Le Gabon. Barreteau, D. 1978. Inventaire des études linguistiques sur les pays d'Afrique Noire d'expression française et sur Madagascar: 493-503. Paris CILF.

Kidda Awak, Mairo. 1990. Historical Background, with Special Reference to Western Africa. Hartmann, R.K.K. (Ed.). 1990. Lexicography in Africa: 8-18. Exeter: Exeter University Press.

Kwenzi-Mikala, J.T. 1998. Parlers du Gabon. Raponda-Walker, A. 1998. Les langues du Gabon: 217. Libreville: Éditions Raponda-Walker.

Kwenzi-Mikala, J.T. 1998a. Localisation des parlers du Gabon. Raponda-Walker, A. 1998. Les langues du Gabon: 215-216. Libreville: Éditions Raponda-Walker.

Largeau, V. 1901. Encyclopédie Pahouine. Eléments de grammaire et dictionnaire français-pahouin. Paris: E. Leroux.

Lejeune, L. 1892. Dictionnaire français-fang ou pahouin, précédé de quelques principes grammaticaux sur cette même langue. Paris: A. Faivre et H. Teillard.

Marling (R.P.). 1872. Dictionnaire fang-français. New York.

Martrou, L. 1924. Lexique fãn-français. Paris: Procure Générale (des Pères du St Esprit)/Abbeville: Imprimerie Paillard.

McArthur, T. 1986. Worlds of Reference. Cambridge: Cambridge University Press.

Metegue N'nah, N. 1984. Lumière sur points d'ombre (contribution à la connaissance de la société gabonaise). Langres: Imprimerie Guéniot. 
Nyangone Assam, B. and P.A. Mavoungou. 2000. Lexicography in Gabon: A Survey. Lexikos 10: 252-274.

Raponda-Walker, A. 1998. Langues du Gabon. Libreville: Éditions Raponda Walker.

Roulet, G. 1866. La rivière Como au Gabon et les populations riveraines. Annales des voyages, t. IV. Paris.

Sarcleux, Ch. s.a. Essai phonétique. Paris.

Smit, M. 1996. Wiegand's Metalexicography as a Framework for a Multilingual, Multicultural, Explanatory Music Education Dictionary for South Africa. Unpublished D.Litt. thesis. Stellenbosch: University of Stellenbosch.

Wiegand, H.E. and A. Kučera. 1981. Brockhaus-Wahrig: Deutsches Wörterbuch auf dem Prüfstand der praktischen Lexikologie. I. Teil: 1. Band (A-BT); 2. Band (BU-FZ). Kopenhagener Beiträge zur germanistischen Linguistik 18: 94-217.

Wiegand, H.E. and A. Kučera. 1982. Brockhaus-Wahrig: Deutsches Wörterbuch auf dem Prüfstand der praktischen Lexikologie. II. Teil: 1. Band (A-BT); 2. Band (BU-FZ); 3. Band (G-JZ). Wiegand, H.E. 1982. Studien zur neuhochdeutschen Lexikographie II. Germanistische Linguistik 3-6/80: 285-373.

Zgusta, L. 1987. Translational Equivalence in a Bilingual Dictionary. Dictionaries 9: 1-43. 